\title{
Systemic Risk and the Financial Crisis: A Primer
}

\author{
James Bullard, Christopher J. Neely, and David C. Wheelock
}

\begin{abstract}
How did problems in a relatively small portion of the home mortgage market trigger the most severe financial crisis in the United States since the Great Depression? Several developments played a role, including the proliferation of complex mortgage-backed securities and derivatives with highly opaque structures, high leverage, and inadequate risk management. These, in turn, created systemic risk - that is, the risk that a triggering event, such as the failure of a large financial firm, will seriously impair financial markets and harm the broader economy. This article examines the role of systemic risk in the recent financial crisis. Systemic concerns prompted the Federal Reserve and U.S. Department of the Treasury to act to prevent the bankruptcy of several large financial firms in 2008. The authors explain why the failures of financial firms are more likely to pose systemic risks than the failures of nonfinancial firms and discuss possible remedies for such risks. They conclude that the economy could benefit from reforms that reduce systemic risks, such as the creation of an improved regime for resolving failures of large financial firms. (JEL E44, E58, G01, G21, G28)
\end{abstract}

Federal Reserve Bank of St. Louis Review, September/October 2009, 91(5, Part 1), pp. 403-17.

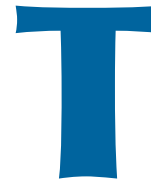

he financial crisis of 2008-09-the most severe since the 1930s-had its origins in the housing market. After several years of rapid growth and profitability, banks and other financial firms began to realize significant losses on their investments in home mortgages and related securities in the second half of 2007. Those losses triggered a full-blown financial crisis when banks and other lenders suddenly demanded much higher interest rates on loans to risky borrowers, including other banks, and trading in many financial instruments declined sharply. A string of failures and nearfailures of major financial institutions-including Bear Stearns, IndyMac Federal Bank, the Federal National Mortgage Association (Fannie Mae), the Federal Home Loan Mortgage Corporation (Freddie Mac), Lehman Brothers, American
International Group (AIG), and Citigroup-kept financial markets on edge throughout much of 2008 and into 2009. The financial turmoil is widely considered the primary cause of the economic recession that began in late 2007.

As individual firms lurched toward collapse, market speculation focused on which firms the government would consider "too big" or "too connected" to allow to fail. Why should any firm, large or small, be protected from failure? For financial firms, the answer centers on systemic risk. Systemic risk refers to the possibility that a triggering event, such as the failure of an individual firm, will seriously impair other firms or markets and harm the broader economy.

Systemic risk concerns were at the heart of the Federal Reserve's decision to facilitate the

James Bullard is president and chief executive officer of the Federal Reserve Bank of St. Louis. Christopher J. Neely is an assistant vice president and economist and David C. Wheelock is a vice president and economist at the Federal Reserve Bank of St. Louis. The authors thank Richard Anderson, Rajdeep Sengupta, and Yi Wen for comments on a previous draft of this article. Craig P. Aubuchon provided research assistance.

(C) 2009, The Federal Reserve Bank of St. Louis. The views expressed in this article are those of the author(s) and do not necessarily reflect the views of the Federal Reserve System, the Board of Governors, or the regional Federal Reserve Banks. Articles may be reprinted, reproduced, published, distributed, displayed, and transmitted in their entirety if copyright notice, author name(s), and full citation are included. Abstracts, synopses, and other derivative works may be made only with prior written permission of the Federal Reserve Bank of St. Louis. 


\section{Figure 1}

\section{U.S. House Prices Relative to the CPI, Rents, and Median Family Income (1995:Q1-2008:Q4)}

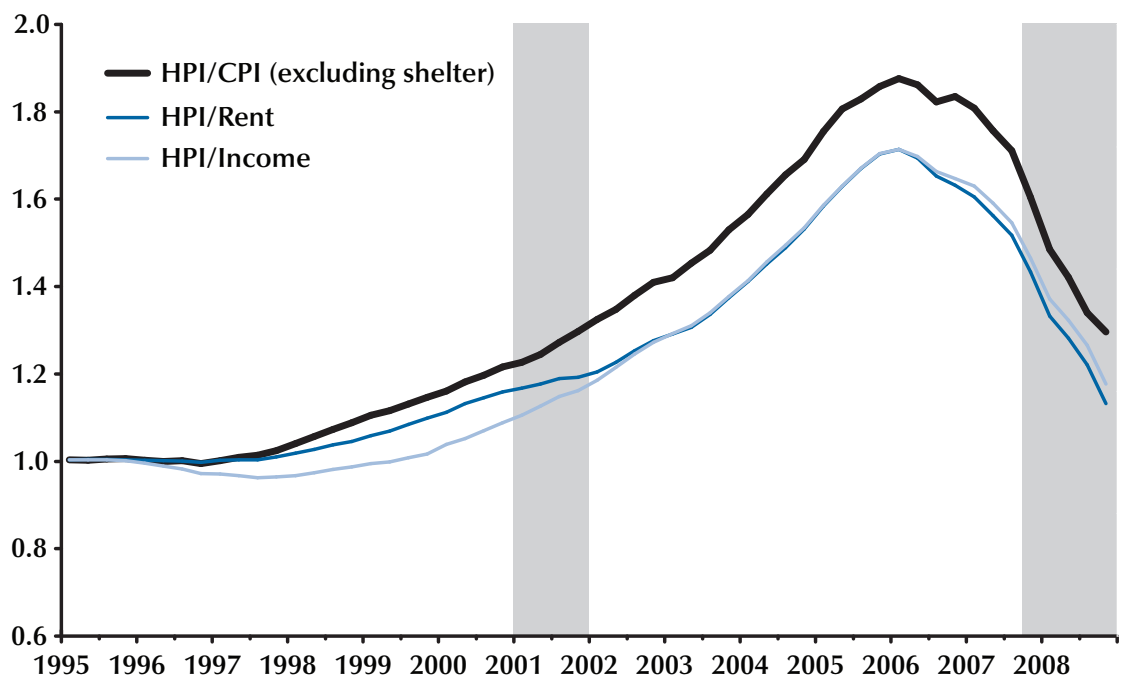

NOTE: The house price index (HPI) shown in the figure is the S\&P/Case-Shiller National Home Price Index; the consumer price index (CPI) data exclude the shelter component of the index; the rent index is a separate component of the CPI; median family income is an aggregated monthly series from the National Association of Realtors; and recession dates (vertical gray bars) are from the National Bureau of Economic Research.

acquisition of Bear Stearns by JPMorgan Chase in March 2008 and the U.S. Department of the Treasury's decisions to place Fannie Mae and Freddie Mac into conservatorship ${ }^{1}$ and to assume control of AIG in September 2008. Federal Reserve Chairman Bernanke (2008b) explained the Fed's decision to facilitate the acquisition of Bear Stearns as follows:

Our analyses persuaded us...that allowing Bear Stearns to fail so abruptly at a time when the financial markets were already under considerable stress would likely have had extremely adverse implications for the financial system and for the broader economy. In particular, Bear Stearns' failure under those circumstances would have seriously disrupted certain key secured funding markets and derivatives mar-

1 A conservatorship is a legal arrangement in which one party is given control of another party's legal or financial affairs. In this case, the Federal Housing Finance Agency was appointed conservator of Fannie Mae and Freddie Mac by the U.S. Treasury Department in accordance with the Federal Housing Finance Regulatory Reform Act of 2008 kets and possibly would have led to runs on other financial firms.

This article describes how the failure of a single financial firm or market could endanger the entire U.S. financial system and economy and how this possibility influenced the response of policymakers to the recent crisis. Further, we explain why failures of financial institutions are more likely to pose systemic risks than failures of nonfinancial firms and discuss possible remedies for the systemic risks exposed by this particular financial crisis. ${ }^{2}$

\section{A BRIEF GUIDE TO THE FINANCIAL CRISIS}

We begin with a brief review of the evolution of the financial crisis and its origins in the hous-

\footnotetext{
2 This article is based on and extends "Systemic Risk and the Macroeconomy" (see Bullard, 2008).
} 
ing market to understand systemic risk in the context of this crisis.

U.S. house prices began to rise far above historical values in the late 1990s. Figure 1 shows the growth in an index of house prices relative to the consumer price index (CPI), an index of residential rents, and median family income, all normalized to equal 1 in the first quarter of 1995. House prices rose rapidly relative to consumer price inflation, rents, and median family income between 1998 and 2006. Analysts attribute the rapid growth in the demand for homes and the associated rise in house prices to unusually low interest rates, large capital inflows, rapid income growth, and innovations in the mortgage market. ${ }^{3}$

A rapid rise in the share of nonprime loans, especially nonprime loans with unconventional terms, was a key feature of the mortgage market during the housing boom. Nonprime loans increased from 9 percent of new mortgage originations in 2001 to 40 percent in 2006 (DiMartino and Duca, 2007). Most nonprime mortgage loans were made to homebuyers with weak credit histories, minimal down payments, low income-toloan ratios, or other deficiencies that prevented them from qualifying for a prime loan. ${ }^{4}$ Many nonprime loans also had adjustable interest rates or other features that kept the initial payments low but subjected borrowers to risk if interest rates rose or house prices declined.

The rise in nonprime loans was accompanied by a sharp increase in the percentage of nonprime loans that originating lenders sold to banks and

\footnotetext{
3 Bernanke (2005) describes the "global saving glut" and changing pattern of international capital flows during the 1990s and early 2000s, and Caballero, Farhi, and Gourinchas (2008) discuss the role of capital inflows in fueling the housing boom. Taylor (2009), by contrast, blames the housing boom primarily on loose monetary policy during 2002-05.

4 Mortgage loans are typically classified as prime or nonprime, depending on the risk that a borrower will default on the loan. Nonprime loans are further distinguished between "subprime" and "alternative-A" (Alt-A), again depending on credit risk. Generally, borrowers qualify for prime mortgages if their credit scores are 660 or higher and the loan-to-value ratio is below 80 percent. Borrowers with lower credit scores or other financial deficiencies, such as a previous record of delinquency, foreclosure or bankruptcy, or higher loan-to-value ratios, are more likely to qualify only for a nonprime loan. See Sengupta and Emmons (2007) for more information about nonprime mortgage lending.
}

other financial institutions. The practice of selling conventional prime mortgages has been common since the 1930s, when the federal government established Fannie Mae to promote the flow of capital to the mortgage market. ${ }^{5}$ The federal government chartered Freddie Mac in 1970 to compete with Fannie Mae, which had been sold to private investors in 1968. Both firms purchase large amounts of prime mortgage loans, which they finance by selling bonds in the capital markets. Before the 1990s, Fannie Mae, Freddie Mac, and other firms rarely purchased nonprime loans. Instead, the originating lenders held most nonprime loans, which comprised a relatively small portion of the mortgage market, until they matured. ${ }^{6}$

When a lender sells a loan rather than holding it until maturity, the lender has less incentive to ensure that the borrower is creditworthy. Many analysts contend that lax underwriting standards contributed to the high rate of nonprime loan delinquencies. ${ }^{7}$ Although purchasers of loans do have an incentive to verify the creditworthiness of borrowers, many evidently failed to appreciate or manage the level of risk in their portfolios during the recent housing boom (Bernanke, 2008a). In some instances, investors may have relied too heavily on the judgments of credit rating agencies. ${ }^{8}$

The banks and other financial institutions that purchased nonprime mortgage loans typically created residential mortgage-backed securities (RMBSs) based on pools of mortgage loans. An

5 Wheelock (2008) discusses the establishment of Fannie Mae and other agencies and programs to alleviate home mortgage distress during the Great Depression.

6 Fannie Mae and Freddie Mac are not permitted to purchase loans that exceed a specific limit (currently $\$ 417,000$ ) except in designated high-cost areas. Further, Fannie Mae and Freddie Mac require minimum documentation and other standards on the loans they purchase, and hence they purchase relatively few nonprime loans.

7 Demyanyk and Van Hemert (2008) and Bhardwaj and Sengupta (2008) provide alternative perspectives on the role of lax underwriting of nonprime loans.

${ }^{8}$ Critics charge that the rating agencies had a conflict of interest because bond issuers paid for the ratings (New York Times, 2007; Fons, 2008a,b). In addition, the rating agencies used inadequate risk models that did not account for a possibility of a serious drop in housing prices. See Fons (2008a,b). 


\section{Figure 2}

\section{U.S. House Prices and Foreclosures}

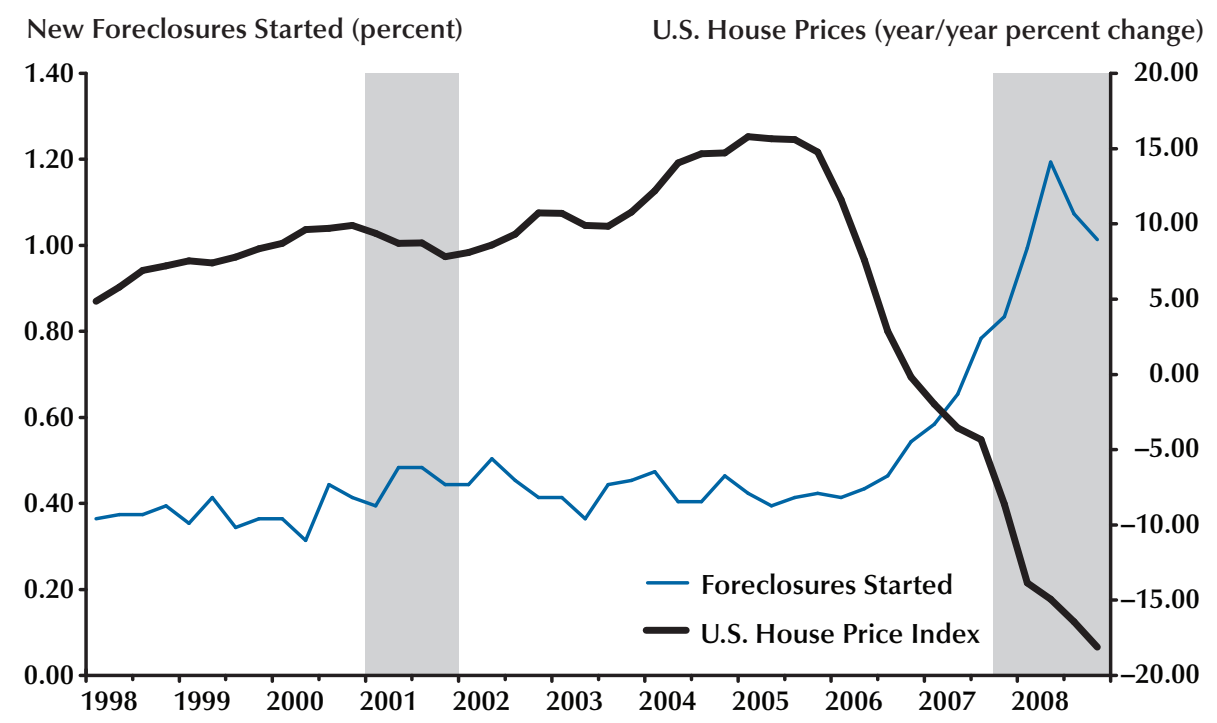

NOTE: Foreclosures data are from the Mortgage Bankers Association; the house price index (HPI) is the S\&P/Case-Shiller National Home Price Index. Vertical gray bars indicate recessions.

RMBS redistributes the income stream from the underlying mortgage pool among bonds that differ by the seniority of their claim. Sometimes additional securities, known as collateralized mortgage obligations (CMOs) or collateralized debt obligations, are created by combining multiple RMBSs (or parts of RMBSs) and then selling portions of the income streams derived from the mortgage pool or RMBSs to investors with different appetites for risk.

The securities rating agencies assigned high ratings to many of the mortgage-related securities created to finance purchases of nonprime loans. As long as house prices were rising, most nonprime loans performed well because borrowers were usually able to refinance or sell their houseat a higher price-if they were unable to make their loan payments. ${ }^{9}$ When house prices began

9 Most nonprime loan originations were refinances of existing mortgages in which borrowers withdrew accumulated equity from their homes (a phenomenon known as a "cash-out" refinance). See Bhardwaj and Sengupta (2009). to fall, many borrowers found that they owed more on their house than it was worth. This situation made it impossible for some borrowers to repay their loan by selling their house or refinancing their mortgage, and it also created an incentive simply to default. Consequently, loan defaults and foreclosures rose sharply, as shown in Figure 2, which plots data on the percentage of home mortgages entering foreclosure in a given quarter and the year-over-year percentage change in the S\&P/ Case-Shiller National Home Price Index.

Rising loan delinquencies caused many RMBSs and CMOs backed by home mortgage loans to default, and investment banks and other investors that held large portfolios of RMBSs and CMOs experienced substantial losses. Ultimately, the decline in house prices and the increase in mortgage loan defaults that began in 2006 were the root cause of the financial crisis. The following sections explore how systemic risks caused losses on nonprime mortgages and mortgage-related securities to disrupt the entire financial system. 


\section{SYSTEMIC RISK}

\section{Systemic Risk, Counterparty Risk, and Asymmetric Information}

In the recent financial crisis, the most important type of risk to the financial system has been "counterparty risk," which is also known as "default risk." 10 Counterparty risk is the danger that a party to a financial contract will fail to live up to its obligations.

Counterparty risk exists in large part because of asymmetric information. Individuals and firms typically know more about their own financial condition and prospects than do other individuals and firms. Much of the recent concern about systemic risk has focused on investment banks that deal in complex financial contracts. Consider the following example: Suppose Bank A purchases an option from Bank B to hedge the risk of a change in the term structure of interest rates. If Bank B later fails, perhaps because of bad investments in home mortgages, then the option sold by Bank B may lose value or even become worthless. Thus, Bank A-which thought it was carefully hedging its risk-is adversely affected by Bank B's problems in housing markets.

Of course, financial firms can protect themselves to some degree in such simple situations. The logic of self-interested behavior combined with market clearing would lead to an appropriate pricing of risk; Bank A would have considered the possibility of the failure of Bank B and taken this into account in its contingency plan. For example, Bank A might require Bank B to post collateral to protect the value of the option in case Bank B failed. But in actual financial markets, arrangements are so complex that the nature of risk that firms face might not be obvious. In addition, the value of collateral fluctuates and thus even carefully collateralized deals are subject to some risk. ${ }^{11}$

\footnotetext{
${ }^{10}$ Taylor (2009) argues that the financial crisis was associated mainly with an increase in counterparty risk and not a shortage of liquidity.

${ }^{11}$ Kiyotaki and Moore (1997) and Pintus and Wen (2008) discuss how procyclical fluctuations in the value of collateral can exacerbate financial booms and busts and contribute to macroeconomic fluctuations.
}

\section{Systemic Risk and Information Cascades}

Sophisticated investors and counterparties will cease to do business with a firm once the firm's weak condition becomes known, as they did with Bear Stearns and Lehman Brothers. However, the inability to sort perfectly among good and bad risks can lead banks and other investors to pull away from nearly all lending during a crisis. The tendency of lenders to seek safe investments during a crisis explains why trading in risky assets declined sharply and their market yields rose relative to yields on federal government debt during 2007-08.

Sometimes all firms in an industry are "tarred by the same brush" and one firm's failure leads investors to shun an entire industry. For example, before the introduction of federal deposit insurance in 1933, the failure of individual banks sometimes caused the public to shift a large portion of its funds from bank deposits into cash. Why should the failure of a single firm cause the public to suspect an entire industry? Again, the answer is related to the fact that people have imperfect information. Because depositors lack complete information about the condition of their bank, the failure of one bank can trigger mass withdrawals by depositors of other banks to avoid losses in the event their own bank fails. Indeed, even if a particular depositor believed that his bank was fundamentally sound, it would still make sense for him to withdraw his money if he thought that withdrawals by other depositors might cause the bank to fail. Banking panics are especially dangerous because large-scale deposit withdrawals can make bank failures more likely, as well as cause banks to reduce their lending in an effort to boost liquidity. Several severe banking panics during the nineteenth and early twentieth centuries resulted in widespread bank failures, financial distress, and economic contractions. ${ }^{12}$

Federal deposit insurance has largely ended the problem of banking panics. When IndyMac Bank was rumored to be near failure in 2008,

\footnotetext{
12 Calomiris and Gorton (2000), Dwyer and Gilbert (1989), and Wicker (2000) are among the numerous studies of the causes and effects of U.S. banking panics. Diamond and Dybvig (1983) provide an important theoretical analysis of banking panics.
} 
many depositors withdrew their funds from the bank. However, rather than holding their funds as cash, IndyMac's depositors merely moved their deposits to other banks. Similarly, the run on IndyMac did not trigger mass deposit withdrawals at other banks.

Panic-like phenomena have occurred during the recent financial crisis, however. For example, when the Reserve Primary Fund, a large money market mutual fund, halted investor redemptions after the net asset value of its shares fell below $\$ 1$ in September 2008, share redemptions rose sharply at other money market mutual funds. Although most money market mutual funds had ample reserves and good assets, investors interpreted the troubles of the Reserve Primary Fund (which held a large amount of Lehman Brothers debt) as a possible indicator of problems at other mutual funds. The federal government quickly guaranteed the value of existing accounts in money market mutual funds to discourage panic withdrawals from such funds.

The dramatic declines in trading volume and liquidity in the markets for mortgage-related securities during the recent financial crisis also reflected investor panic. Trading in all RMBSs declined sharply when defaults and ratings downgrades made investors wary of RMBSs in general. Heavy reliance by investors on the evaluation of mortgage instruments by the rating agencies may have exacerbated swings in market liquidity. For example, a ratings downgrade, especially of a previously highly rated security, could induce panic selling by signaling possible downgrades or losses on similar securities. Ratings downgrades and declining asset values can also force borrowers to post additional collateral to maintain a given level of borrowing. AIG collapsed in September 2008 when it was unable to raise additional collateral in the wake of a downgrade of its debt rating (Son, 2008). In general, deterioration in the collateral value of borrower assets was an important amplification mechanism during the recent financial crisis. Falling asset prices caused lenders to demand more collateral, which caused borrowers to dump risky assets, thereby exacerbating declines in their market values and leading to further demands for more collateral (Brunnermeier, 2008).

\section{Why the Financial System Is Special}

Many aspects of systemic risk are not unique to financial institutions or markets. The failure of a nonfinancial firm, such as an automobile manufacturer, will affect the firm's suppliers and dealerships, as well as the local economies where manufacturing plants and other operations are located. By the same token, a default by an airline company on its debt obligations might cause investors to shun the debt of other airline companies if investors believe that the default reflected an industry-wide problem, such as rising fuel prices. Still, over the past decade, some very large firms have failed, including Enron, WorldCom, and several major airlines, yet none caused significant problems beyond its immediate shareholders, employees, suppliers, and customers. The failure of a nonfinancial firm would rarely threaten the solvency of a competitor, let alone significantly affect the economy more broadly. Instead, the failure of a large firm could increase the market shares and profitability of the remaining firms in an industry, as well as provide opportunities for smaller firms to enter previously inaccessible markets.

Why do we think the failure of a large financial firm presents systemic risks that the failure of a nonfinancial firm does not? There are at least three reasons.

The first is interconnectedness. In the normal course of business, large commercial and investment banks lend and trade with each other through interbank lending and deposit markets, transactions in over-the-counter (OTC) derivatives, and wholesale payment and settlement systems. Settlement risk - the risk that one party to a financial transaction will default after the other party has delivered-is a major concern for large financial institutions whose daily exposures routinely run into many billions of dollars. The lightning speed of financial transactions and the complex structures of many banks and securities firms make it especially difficult for a firm to fully monitor the counterparties with which it deals, let alone the counterparties of counterparties. The rapid failure of a seemingly strong bank could potentially expose other firms to large losses. 
Even firms that do not transact directly with the affected bank can be exposed through their dealings with affected third parties. ${ }^{13}$

A second reason why the financial sector is especially vulnerable to systemic risk is leverage. Compared with most nonfinancial firms, banks and other financial institutions are highly leveraged-that is, they fund a substantial portion of their assets by issuing debt rather than selling equity. During the housing boom, many banks, hedge funds, and other firms that invested heavily in mortgage-related securities financed their holdings by borrowing heavily in debt markets. Investment banks were especially highly leveraged before the crisis, with debt-to-equity ratios of approximately 25 to 1 . That is, for every dollar of equity, investment banks issued an average of $\$ 25$ of debt. By comparison, commercial banks, which are subject to minimum capital requirements, had leverage ratios of approximately 12 to $1 .{ }^{14}$ High leverage meant that financial firms enjoyed high rates of return on equity when times were good but also a high risk of failing when markets turned against them.

Because investment banks held a mere $\$ 4$ of equity for every $\$ 100$ of assets on their balance sheets, a relatively modest (4 percent) decline in the value of an investment bank's assets would wipe out the bank's equity, forcing it to raise additional capital and/or sell some of its assets. Many investment banks and other financial institutions sustained large losses on their portfolios of RMBSs and were forced to raise additional capital to remain solvent. Similarly, Fannie Mae and Freddie Mac ran into financial difficulties in part because of their extreme leverage. The federal government placed both Fannie Mae and Freddie Mac into conservatorship in July 2008 because losses on their portfolios of mortgages and RMBSs drove the firms to the brink of insolvency. Had those firms held more capital, they could have withstood larger losses without becoming insolvent.

\footnotetext{
${ }^{13}$ Lagunoff and Schreft (2001) present a model in which a financial crisis can arise as losses spread among firms whose portfolios are linked to those of other firms.

${ }^{14}$ See Economic Report of the President (2009, p. 71).
}

A third reason why the financial sector is especially vulnerable to systemic risk is the tendency of financial firms to finance their holdings of relatively illiquid long-term assets with shortterm debt. Not only are financial institutions typically highly leveraged, but the nature of their business entails an inherent mismatch in the maturities of their assets and liabilities that can make them vulnerable to interest rate or liquidity shocks. Most financial intermediaries borrow short and lend long — that is, they fund long-term, relatively illiquid investments with short-term debt. For example, commercial banks traditionally have used demand deposits, which depositors can withdraw at any time, to fund loans and other long-term investments. Many investment banks and securities firms rely heavily on commercial paper, repurchase agreements (repos), ${ }^{15}$ and other short-term funding sources to finance long-term investments. If depositors suddenly pull their funds from a commercial bank or lenders refuse to purchase a securities firm's commercial paper or repos, the bank or securities firm could be forced into bankruptcy. Bear Stearns collapsed when investors refused to purchase the firm's short-term debt. Other firms faced sharply higher funding costs in 2007-08 as markets reevaluated the creditworthiness of borrowers. The speed with which the markets can "turn off the tap" makes financial institutions especially vulnerable to temporary disruptions of liquidity in financial markets. ${ }^{16}$

\section{MITIGATING SYSTEMIC RISK}

Recognizing the problem of systemic risk, financial firms have long cooperated to limit risks associated with the failures of other financial firms. For example, before the creation of the Federal Reserve System in 1913, commercial banks devised clearinghouse arrangements in an

\footnotetext{
${ }^{15} \mathrm{~A}$ repo is a trade in which one party agrees to sell securities to a second party and to buy those securities back at a prespecified price and date. It amounts to collateralized borrowing.

${ }^{16}$ Acharya, Gale, and Yorulmazer (2009) present a model that can explain a sudden collapse of liquidity in a financial market associated with a change in the information structure of the assets traded in the market.
} 
attempt to protect themselves from banking panics. The primary purpose of a clearinghouse is to clear checks and other forms of payment among member banks. In the nineteenth century, clearinghouses developed mechanisms to protect their members from banking panics and to provide additional liquidity for banks facing deposit runs. For example, clearinghouse members could borrow certificates to settle their balances with other member banks in lieu of cash or other reserves. Further, clearinghouse members collectively guarantee the payment obligations of members threatened by deposit withdrawals. ${ }^{17}$

Financial market exchanges, such as the Chicago Mercantile Exchange, are also private arrangements that limit systemic risks. Securities and commodities exchanges arose centuries ago to settle trades efficiently under clear, fixed rules. Exchanges are the central counterparty to every transaction. Like bank clearinghouses, exchanges reduce default risk by requiring their members to meet minimum capital and disclosure requirements. If a member of the exchange does default, the other members bear that firm's obligations according to the exchange's loss-sharing rules. Thus, membership requirements and loss-sharing arrangements lessen the risk that default by one firm will adversely affect other members of the exchange.

Many derivatives trade in OTC markets, which consist of financial institutions doing business directly with each other rather than through an exchange. Many analysts have identified weaknesses in OTC derivatives markets, especially in the market for credit default swaps, as important contributors to the recent financial crisis. ${ }^{18}$

The use of credit default swaps and other financial derivatives has grown enormously in recent years. Although useful for hedging risks, the proliferation of OTC derivatives is widely believed to have increased systemic risks in the financial system by increasing the extent to which

${ }^{17}$ See Gorton (1985), Timberlake (1984), and White (1983, pp. 74-83) for more information about the role of clearinghouses in mitigating banking panics.

${ }^{18}$ Wallison (2008) discusses the credit default insurance (or swap) market, and Schinasi et al. (2001) describe the OTC derivatives market. large financial firms are interconnected and by reducing transparency. Many analysts believe that these risks could be substantially reduced by establishing a central exchange or clearinghouse for derivatives trading. ${ }^{19}$ Because exchangetraded derivatives are standardized contracts that are traded among many parties every day, they could be valued more precisely than the custom products traded among individual firms on OTC markets. In addition, the requirement for exchange participants to post margins against potential losses and mark positions to market daily would help reduce counterparty risks. Exchange participants that cannot cover their losses will have their positions closed out before the losses become too large.

Cooperative arrangements, such as clearinghouses and exchanges, are one way of reducing systemic risks. However, in many circumstances private measures might be insufficient to ameliorate systemic risk. For example, individual firms could be reluctant to reveal private business information to competitors, which might impair a loss-sharing agreement. Further, firms often have little incentive to mitigate costs borne by others. Thus, a firm whose failure poses systemic risk will tend to behave less cautiously than society would desire and, hence, government involvement might be necessary to limit systemic risks. ${ }^{20}$

\section{Proposals for Government Policies to Control Systemic Risks}

The recent financial crisis has prompted numerous proposals for enhanced government regulation and supervision of large financial firms and markets to address systemic risks. Many proposals call for increased supervision of systemically important financial institutions, as well as new rules for resolving insolvent firms.

\footnotetext{
${ }^{19}$ For example, see Bernanke (2008c) and Counterparty Risk Management Policy Group III (2008)

20 Systemic risk constitutes a "negative externality" in the sense that the actions of one firm harm others. The situation is analogous to a firm that pollutes the environment. Because others bear at least some of the costs of the pollution, the firm will tend to pollute more than it would if it had to compensate others for these costs. Negative externalities are an example of a market failure that may require government intervention to ameliorate.
} 
Other proposals recommend regulation to limit risk-taking and to ensure ample liquidity in financial markets. This section reviews some of the regulatory and legal proposals suggested in response to the recent crisis.

Many reform proposals call for the creation of a systemic financial regulator with responsibilities for "macroprudential" oversight of the financial system. A macroprudential regulator would consider broad economic trends and the impact of a firm's actions on the entire financial system, not just the firm's own risk of default (Bernanke, 2008c). To some extent, regulators already consider broad economic trends and effects, but several proposals argue for bringing all large or systemically important financial institutions under the umbrella of a systemic regulator. ${ }^{21}$

One justification for the regulation and supervision of systemically important firms is that governments are unlikely to permit such firms to fail, or if they do fail, the government will substantially protect many, if not all, of the firm's creditors from loss. Such a government guarantee-either explicit or implicit—can encourage firms to take greater risks than they otherwise would, which increases the likelihood of their failure. ${ }^{22}$ Consequently, regulation and supervision is required to offset the incentive to take excessive risk.

Federal deposit insurance is one example of a government guarantee that can encourage excessive risk-taking. Without deposit insurance, rational, fully informed depositors would require banks with risky assets to hold more capital or pay higher deposit rates than banks with less-risky

\footnotetext{
${ }^{21}$ For example, the Group of Thirty (2009, p. 17) argues that at the start of 2008, there were five U.S. investment banks (Bear Stearns, Goldman Sachs, Lehman Brothers, Merrill Lynch, and Morgan Stanley), one insurance company (AIG), and two governmentsponsored enterprises (Fannie Mae and Freddie Mac) that were systemically significant and therefore should have been subject to stringent regulation and supervision. During 2008, all but two of those firms (Goldman Sachs and Morgan Stanley) failed or suffered large losses that required government intervention, and both Goldman Sachs and Morgan Stanley became bank holding companies.

22 "Moral hazard" describes the idea that individuals and firms engage in riskier behavior when they are protected from the danger that such behaviors create. For example, a person who purchases fire insurance might be less concerned with fire hazards than one who would personally bear the full cost of a fire.
}

assets. However, with insurance, depositors have little incentive to monitor the risks their banks take; hence, deposit insurance gives banks an incentive to assume greater risks than they otherwise would. ${ }^{23}$

Whereas deposit insurance is an explicit guarantee, the public's expectation that the federal government would stand behind the liabilities of Fannie Mae and Freddie Mac is an example of an implicit guarantee. The perception that the government would guarantee the liabilities of Fannie Mae and Freddie Mac enabled those firms to borrow at relatively low interest rates to fund their purchases of mortgages and RMBSs, including securities backed by nonprime mortgages. Fannie Mae and Freddie Mac grew rapidly and operated with much lower capital ratios than other financial firms. Ultimately, financial losses eroded their thin capital cushions and pushed both Fannie Mae and Freddie Mac to the brink of failure before they were placed into government conservatorship. ${ }^{24}$

Many policymakers and analysts have called for new rules for shutting down large financial firms that become insolvent. The current bankruptcy regime is widely criticized as inadequate for dealing with failures of systemically important financial institutions. ${ }^{25}$ Delays and uncertainties inherent in the bankruptcy process of a systemically important firm could precipitate or exacerbate a financial crisis.

Several reform proposals advocate subjecting nonbank financial firms to "prompt corrective action" in the event their capital ratios fall below prescribed levels. The Federal Deposit Insurance Corporation Improvement Act of 1991 already

\footnotetext{
${ }^{23}$ Merton (1977) shows that banks maximize the value of deposit insurance to themselves by maximizing their risk. Capital requirements and other measures can limit the excessive risk-taking encouraged by deposit insurance. Many analysts blame lax regulation and supervision, coupled with an increase in deposit insurance coverage, for increased risk-taking and the high failure rates of banks and, especially, savings and loan associations during the 1980s. For example, see Kane (1989) and White (1991).

${ }^{24}$ Poole (2002, 2003, and 2007) was among those warning of the risks inherent with the implicit government guarantee of Fannie Mae and Freddie Mac debt. Stern and Feldman (2004) discuss the effects of "too big to fail" policies in general.

${ }^{25}$ For example, see Bernanke (2008c) and Congressional Oversight Panel (2009, p. 24).
} 
mandates prompt corrective action for commercial banks. For example, bank supervisors can limit the growth, executive compensation, and payment of dividends by undercapitalized banks. Supervisors can also place critically undercapitalized banks into conservatorship or receivership. ${ }^{26}$ Federal Reserve Chairman Bernanke (2008c) and others argue that prompt corrective action could reduce systemic risks and discourage large financial holding companies and nonbank financial firms from taking excessive risks. Further, the authority to place a critically undercapitalized firm into conservatorship or receivership would enable the government to resolve failures in an orderly way that imposes the failing firm's losses on the firm's creditors and equity holders rather than on taxpayers.

Prompt corrective action is one potential component of a general strengthening of the oversight of large financial firms. Another potential component is a more comprehensive approach to the supervision of complex and systemically important financial firms. Proponents argue that broader supervision of systemically significant firms might have prevented the failure of AIG, which required a government rescue to avoid bankruptcy in September 2008.

AIG is a large financial conglomerate with global operations. The traditional business of AIG is insurance-automobile, life, and so on. In the United States, state government authorities regulate insurance firms-New York State in the case of AIG. State insurance regulations and supervision are designed to ensure the solvency of insurance companies so that they are fairly certain to meet their contingent claims. But insurance regulators have little or no oversight of the other subsidiaries and operations of conglomerates such as AIG. Besides owning an insurance company, AIG also owns a federally chartered savings bank (AIG Bank, FSB), which places AIG under the supervision of the Office of Thrift Supervision. Bank and thrift regulators, however, traditionally

\footnotetext{
${ }^{26}$ Aggarwal and Jacques (1998) and Spong (2000, pp. 84-98) provide additional information about commercial bank capital requirements and prompt corrective action. Evanoff and Wall (2003) argue that the use of subordinated debt spreads might be useful to trigger prompt corrective action.
}

have focused on the condition of the depository institution rather than on the systemic risks posed by its parent holding company. The Office of Thrift Supervision has neither the resources to supervise the activities of the entire conglomerate nor the mandate to regulate the extent to which AIG poses systemic risk to the financial system.

AIG's unregulated activities, notably the underwriting of credit default insurance, created substantial losses as the housing market slumped badly in 2006-08. These unregulated operations had grown so large that government officials feared that AIG's sudden collapse could impose severe losses on other firms and seriously impair the functioning of the entire financial system. To avoid this outcome the U.S. Treasury and Federal Reserve provided AIG with loans and a capital injection in September 2008 when it appeared that the firm would default on its outstanding debts.

Many proposals for reforming financial regulation call for the supervision of large, complex financial institutions such as AIG by strong regulators with sweeping oversight and enforcement powers that can focus on the systemic risks posed by such organizations. ${ }^{27}$ Brunnermeier et al. (2009) argue that an effective macroprudential regulator must have the political independence to impose unpopular measures. To limit discretion, the study argues, regulation should follow preset rules as much as possible. Writing rules to cover every possible contingency is difficult if not impossible, however, and before assigning sweeping oversight and enforcement authority to a systemic regulator, the scope of the regulator's authority would have to be carefully delineated.

In addition to enhanced macroprudential oversight, proposals for mitigating systemic risks in the financial system include the imposition of minimum capital requirements on large financial firms, regulations on the use of short-term debt to finance holdings of long-term assets, and changes to market value accounting rules.

Many analysts contend that extreme leverage contributed to the recent financial crisis by making large financial firms especially vulnerable to

\footnotetext{
${ }^{27}$ For example, see Brunnermeier et al. (2009), Congressional Oversight Panel (2009), Group of Thirty (2009), and Paulsen et al. (2008).
} 
losses. This view has prompted proposals to strengthen capital requirements for commercial banks and to extend those requirements to previously unregulated financial firms, such as investment banks. Some analysts argue that large, systemically significant firms should be required to hold more capital as a percentage of their assets than smaller firms (e.g., Congressional Oversight Panel, 2009, p. 26).

Some proposals call for discouraging the funding of long-term, illiquid assets with short-term debt. A firm that cannot roll over its short-term debt could be forced to sell assets, and if many firms are in the same predicament, then asset prices could decline sharply. Such price declines would impose further losses on firms, forcing a spiral of still more sales and further price declines. As the recent financial crisis intensified, especially in September 2008, firms that relied heavily on short-term debt faced sharply higher interest rates as banks suddenly became less willing to lend and investors fled to the safety of U.S. Treasury securities. ${ }^{28}$ Future systemic risks could be reduced by discouraging excessive leveraging and the use of short-term debt to fund long-term asset holdings, for example, by requiring firms to hold more capital against long-term, relatively illiquid assets funded with short-term debt than against more-liquid assets or assets funded with long-term debt (e.g., Brunnermeier et al., 2009, pp. 38-39). Kotlikoff and Leamer (2009) offer a more radical solution to the problem of short-term debt financing illiquid assets: "limited-purpose banking." This scheme would convert all financial firms to mutual funds so that individual depositors, not the financial firms, would bear the risk of the asset holdings.

Noting the tendency of financial firms to increase their use of leverage when asset prices are rising and to reduce leverage when prices are falling, some analysts argue that capital requirements should become increasingly stringent when asset prices are rising. Some proposals call for tying capital requirements explicitly to the growth in the value of a bank's assets (e.g., Congressional

\footnotetext{
${ }^{28}$ The danger of issuing short-term debt is not limited to firms. Neely (1996) describes the role of short-term debt in triggering Mexico's December 1994 peso crisis.
}

Oversight Panel, 2009, pp. 27-28); others call on bank supervisors to encourage banks to build capital and liquidity when times are good and allow banks to draw down their buffers during difficult times. For example, the Group of Thirty (2009, p. 43) recommends capital requirements "expressed as a broad range within which capital ratios should be managed, with the expectation that, as part of supervisory guidance, firms will operate at the upper end of such a range in periods when markets are exuberant and tendencies for underestimating and underpricing risk are great."

One of the more hotly debated issues surrounding the recent financial crisis is the extent to which fair value accounting rules contributed to the crisis. In textbook financial markets, valuations are the considered outcomes of the views of rational, relatively risk-tolerant speculators with deep pockets. In the real world, however, imperfect information and limited risk tolerance are facts of life that can inhibit the rational speculation necessary to drive prices back to long-term fundamental values. Trading in certain assets might cease during a crisis or trades might occur at widely disparate prices, making the determination of their market value problematic just when the value of transparency is greatest. In addition, by forcing financial firms to realize declines in asset prices immediately, mark-to-market rules might exacerbate a crisis by encouraging asset sales when prices are already falling, leading to further write-downs and financial losses. ${ }^{29}$

The Group of Thirty (2009, p. 46) calls for applying "more realistic" accounting guidelines to less-liquid assets and distressed markets but is generally supportive of fair value accounting. Similarly, Brunnermeier et al. (2009, pp. 36-37) advocate a "mark-to-funding" approach to fair value accounting in which the value of an asset is tied to the funding of that asset. For example, if an asset that matures in 20 years is financed

\footnotetext{
${ }^{29}$ Blanchard (2008) compares the current financial crisis with nineteenth-century bank runs. He points out that the opacity of the mortgage-backed assets has served to amplify the financial crisis by making those assets particularly difficult to value, lowering their resale price, and increasing uncertainly about financial firms' solvency. Similarly, the high degree of leverage of financial institutions increases the probability that any losses will lead to insolvency.
} 
with debt that matures in 30 days, the asset should be valued at the expected price of the asset in 30 days. Of course, calculating expected future prices in any reasonable way is difficult and the authors acknowledge that their scheme would give firms some discretion over the valuation of their assets. However, they argue that it would more accurately relate the value of assets to funding risks.

\section{CONCLUSION}

The recent financial crisis has claimed many victims. Several prominent firms, including Bear Stearns, Lehman Brothers, AIG, Fannie Mae, and Freddie Mac, have gone bankrupt or required government intervention to prevent their failure. When the U.S. Treasury Department and the Federal Reserve intervened to prevent a failure, their goal was to protect the financial systemand the economy-from systemic risk.

Financial firms are much more susceptible to systemic risk than nonfinancial firms because financial firms are typically highly interconnected with one another, highly leveraged, and tend to use short-term debt to finance their holdings of long-term, relatively illiquid assets. In the recent crisis, the possible failure of counterparties in complex transactions created systemic risk.

Financial firms are cognizant of systemic risk and traditionally have tried to reduce their vulnerability to it by participating in clearinghouses or trading through financial exchanges. Nevertheless, because firms do not bear all the costs of their own failure, government has a role to play in limiting systemic risk in the financial system to protect the broader economy. Analysts have proposed regulatory reforms to reduce the danger from systemic risk in the future. In particular, some advocate the creation of a powerful macroprudential regulator that considers a firm's impact on the stability of the entire financial system. Other ideas for reducing systemic risk include limiting the use of leverage and short-term debt and revising market value accounting rules.

It is too soon to fully determine the causes of the recent financial crisis. Asset price booms and busts that impair the financial system and the entire economy have occurred before. However, the complex nature of recently developed financial instruments has transmitted the consequences of the housing bust to the entire financial system and, ultimately, to the overall economy. Accordingly, many analysts favor measures to increase the use of organized exchanges for trading derivatives.

An improved regime for resolving large insolvent financial firms would limit systemic risk and excessive risk-taking. When the government has intervened to protect the economy from the failure of a large systemically important financial firm, the shareholders of these firms usually received little or no value for their equity and their senior managers were dismissed or subject to compensation limits. However, bondholders doubtless received more compensation than they would have in the absence of government intervention. A legal reform that permits rapid resolution of failing financial firms, including appropriate reductions in payments to bondholders, would help to create incentives for bondholders to be mindful of the risk of their investments. This, in turn, would discourage excessive risk-taking by increasing the borrowing costs for risky firms. The economy could benefit from reforms that reduce the risks to the financial system imposed by firms that are "too big to fail."

\section{REFERENCES}

Acharya, Viral; Gale, Douglas and Yorulmazer, Tanju. "Rollover Risk and Market Freezes.” New York University and Federal Reserve Bank of New York Working Paper, October 2008, updated February 2009; www.newyorkfed.org/research/conference/ 2009/cblt/Acharya-Gale-Yorulmazer.pdf.

Aggarwal, Raj and Jacques, Kevin T. “Assessing the Impact of Prompt Corrective Action on Bank Capital and Risk." Federal Reserve Bank of New York Economic Policy Review, October 1998, pp. 23-32; www.newyorkfed.org/research/epr/98v04n3/ 9810agga.pdf.

Bernanke, Ben S. "The Global Saving Glut and the U.S. Current Account Deficit." Remarks at the Homer Jones Memorial Lecture, St. Louis, April 14, 
2005; www.federalreserve.gov/boarddocs/speeches/ 2005/20050414/default.htm.

Bernanke, Ben S. "Risk Management in Financial Institutions." Speech at the Federal Reserve Bank of Chicago's Annual Conference on Bank Structure and Competition, Chicago, May 15, 2008a; www.federalreserve.gov/newsevents/speech/ bernanke20080515a.htm.

Bernanke, Ben S. "Financial Regulation and Financial Stability." Speech at the Federal Deposit Insurance Corporation's Forum on Mortgage Lending for Low and Moderate Income Households, Arlington, Virginia, July 8, 2008b; www.federalreserve.gov/ newsevents/speech/bernanke20080708a.htm.

Bernanke, Ben S. "Reducing Systemic Risk.” Speech at the Federal Reserve Bank of Kansas City's Annual Economic Symposium in Jackson Hole, Wyoming, August 22, 2008c; www.federalreserve.gov/ newsevents/speech/bernanke20080822a.htm.

Bhardwaj, Geetesh and Sengupta, Rajdeep. "Where's the Smoking Gun? A Study of Underwriting Standards for U.S. Subprime Mortgages.” Working Paper No. 2008-036B, Federal Reserve Bank of St. Louis, October 27, 2008; revised May 2009; http://research.stlouisfed.org/wp/2008/2008-036.pdf.

Bhardwaj, Geetesh and Sengupta, Rajdeep. "Did Prepayments Sustain the Subprime Market?" Working Paper No. 2008-039B, Federal Reserve Bank of St. Louis, April 2009;

http://research.stlouisfed.org/wp/2008/2008-039.pdf.

Blanchard, Olivier J. "The Crisis: Basic Mechanisms, and Appropriate Policies." Working Paper No. 09-01, MIT Department of Economics, December 29, 2008; http://ssrn.com/abstract=1324280.

Brunnermeier, Markus. "Deciphering the 2007-08 Liquidity and Credit Crunch." Working paper, Princeton University, May 2008.

Brunnermeier, Markus K.; Crockett, Andrew; Goodhart, Charles A.; Persaud, Avinash D. and Shin, Hyun. The Fundamental Principles of Financial Regulation: Geneva Reports on the World Economy 11 (Preliminary Conference Draft). London: Centre for
Economic Policy Research, 2009;

www.voxeu.org/reports/Geneva11.pdf.

Bullard, James. "Systemic Risk and the Macroeconomy: An Attempt at Perspective." Speech at Indiana University on October 2, 2008; www.stlouisfed.org/ newsroom/speeches/2008 10 02.cfm.

Caballero, Ricardo J.; Farhi, Emmanuel and Gourinchas, Pierre-Olivier. "Financial Crash, Commodity Prices and Global Imbalances." NBER Working Paper 14521, National Bureau of Economic Research, November 17, 2008; www.nber.org/ papers/w14521.pdf?new_window=1.

Calomiris, Charles W. and Gorton, Gary. "The Origins of Banking Panics: Models, Facts and Bank Regulation," in Charles W. Calomiris, ed., U.S. Bank Deregulation in Historical Perspective. New York: Cambridge University Press, 2000, pp. 93-163.

Congressional Oversight Panel. "Special Report on Regulatory Reform.” January 2009; http://cop.senate.gov/documents/cop-012909report-regulatoryreform.pdf.

Counterparty Risk Management Policy Group III. "Containing Systemic Risk: The Road to Reform." August 6, 2008; www.crmpolicygroup.org/docs/ CRMPG-III.pdf.

Demyanyk, Yuliya S. and Van Hemert, Otto. "Understanding the Subprime Mortgage Crisis." Advance Access published online on May 4, 2009, in Review of Financial Studies; doi:10.1093/rfs/hhp033.

Diamond, Douglas and Dybvig, Philip. "Bank Runs, Deposit Insurance, and Liquidity." Journal of Political Economy, June 1983, 91(3), pp. 401-19.

DiMartino, Danielle and Duca, John V. "The Rise and Fall of Subprime Mortgages.” Federal Reserve Bank of Dallas Economic Letter, November 2007, 2(11); www.dallasfed.org/research/eclett/2007/el0711.html.

Dwyer, Gerald P. Jr. and Gilbert, R. Alton. "Bank Runs and Private Remedies.” Federal Reserve Bank of St. Louis Review, May/June 1989, pp. 43-61; http://research.stlouisfed.org/publications/review/ 89/05/Remedies May Jun1989.pdf. 
Economic Report of the President, 2009. Washington, DC: U.S. Government Printing Office, January 2009; www.gpoaccess.gov/eop/2009/2009_erp.pdf.

Evanoff, Douglas D. and Wall, Larry D. "Subordinated Debt and Prompt Corrective Regulatory Action." Working Paper Series No. WP 2003-03, Federal Reserve Bank of Chicago, 2003; www.chicagofed.org/ publications/workingpapers/papers/wp2003-03.pdf.

Fons, Jerome S. "Rating Competition and Structured Finance." Journal of Structured Finance, Fall 2008a, 14(3).

Fons, Jerome S. Testimony of Jerome S. Fons Before the Committee on Oversight and Government Reform United States House of Representatives, October 22, 2008b; http://oversight.house.gov/ documents/20081022102726.pdf.

Gorton, Gary. "Clearinghouses and the Origin of Central Banking in the United States." Journal of Economic History, June 1985, 45(2), pp. 277-83.

Group of Thirty. Financial Reform: A Framework for Financial Stability. Washington, DC: The Group of Thirty, 2009; www.group30.org/pubs/ recommendations.pdf.

Kane, Edward J. The S\&L Insurance Mess: How Did It Happen? Washington, DC: Urban Institute Press, 1989.

Kiyotaki, Nobuhiro and Moore, John. "Credit Cycles." Journal of Political Economy, April 1997, 105(2), pp. 211-48.

Kotlikoff, Laurence J. and Leamer, Edward. "A Banking System We Can Trust.” Forbes, April 23, 2009; www.forbes.com/2009/04/22/loan-mortgage-mutualfund-wall-street-opinions-contributors-bank.html.

Lagunoff, Roger and Schreft, Stacey L. "A Model of Financial Fragility.” Journal of Economic Theory, July/August 2001, 99(1-2), pp. 220-64.

Merton, Robert C. “An Analytic Derivation of the Cost of Deposit Insurance and Loan Guarantees: An Application of Modern Option Pricing Theory.”
Journal of Banking and Finance, June 1977, 1(1), pp. 3-11.

Neely, Christopher J. "The Giant Sucking Sound: Did NAFTA Swallow the Peso?” Federal Reserve Bank of St. Louis Review, July/August 1996, 78(4), pp. 33-47; http://research.stlouisfed.org/publications/ review/96/07/9607cn.pdf.

New York Times. "Senators Accuse Rating Agencies of Conflicts of Interest in Market Turmoil," September 26, 2007; www.nytimes.com/2007/ 09/26/business/worldbusiness/26iht-credit.4. 7646763.html.

Paulsen, Henry M. Jr.; Steel, Robert K.; Nason, David G. et al: The Department of the Treasury Blueprint for a Modernized Financial Regulatory Structure, March 2008; www.treas.gov/press/releases/reports/ Blueprint.pdf.

Pintus, Patrick A. and Wen, Yi. "Excessive Demand and Boom-Bust Cycles." Working Paper 2008-014B, Federal Reserve Bank of St. Louis, June 2008; http://research.stlouisfed.org/wp/2008/2008-014.pdf.

Poole, William. "Financial Stability." Remarks at the Council of State Governments Southern Legislative Conference Annual Meeting, New Orleans, Louisiana, August 4, 2002; http://fraser.stlouisfed.org/historicaldocs/wp2002/ download/41143/20020804.pdf.

Poole, William. "Housing in the Macroeconomy." Remarks at the Office of Federal Housing Enterprise Oversight Symposium, Washington, DC, March 10, 2003; http://fraser.stlouisfed.org/historicaldocs/wp2003/download/41135/20030310.pdf.

Poole, William. "Reputation and the Non-Prime Mortgage Market.” Remarks at the St. Louis Association of Real Estate Professionals. July 20, 2007; http://fraser.stlouisfed.org/historicaldocs/ wp2007/download/40917/20070720.pdf.

Schinasi, Garry J.; Craig, R. Sean; Drees, Burkhard and Kramer, Charles. "Modern Banking and OTC Derivatives Markets: The Transformation of Global Finance and Its Implications for Systemic Risk.” Occasional Paper No. 203, International Monetary 
Fund, January 9, 2001;

www.imf.org/external/pubs/nft/op/203/.

Sengupta, Rajdeep and Emmons, William R. "What Is Subprime Lending?" Federal Reserve Bank of St. Louis, Economic Synopses No. 13, 2007; http://research.stlouisfed.org/publications/es/07/ ES0713.pdf.

Son, Hugh. "AIG Plunges as Downgrades Threaten Quest for Capital.” Bloomberg.com, September 16, 2008; www.bloomberg.com/apps/news?pid= 20601087\&sid=aP5rm0.62 wqo.

Spong, Kenneth. Banking Regulation: Its Purposes, Implementation, and Effects. Fifth edition. Kansas City, MO: Federal Reserve Bank of Kansas City, 2000; www.kansascityfed.org/banking/ bankingpublications/RegsBook2000.pdf.

Stern, Gary H. and Feldman, Ron J. Too Big to Fail: The Hazards of Bank Bailouts. Washington, DC: Brookings Institution Press, 2004.

Taylor, John B. Getting Off Track: How Government Actions and Intervention Caused, Prolonged, and Worsened the Financial Crisis. Stanford, CA: Hoover Institution Press, 2009.
Timberlake, Richard H. Jr. "The Central Banking Role of Clearinghouse Associations." Journal of Money, Credit, and Banking, February 1984, 16(1), pp. 1-15.

Wallison, Peter J. "Everything You Wanted to Know about Credit Default Swaps-But Were Never Told" (American Enterprise Institute for Public Policy Research Outlook Series). December 2008; www.aei.org/docLib/20090107_12DecFSOg.pdf.

Wheelock, David C. “The Federal Response to Home Mortgage Distress: Lessons from the Great Depression.” Federal Reserve Bank of St. Louis Review, May/June 2008, 90(3 Part 1), pp. 133-48; http://research.stlouisfed.org/publications/review/ 08/05/Wheelock.pdf.

White, Eugene N. The Regulation and Reform of the American Banking System, 1900-1929. Princeton, NJ: Princeton University Press, 1983.

White, Lawrence J. The S\&L Debacle: Public Policy Lessons for Bank and Thrift Regulation. New York: Oxford University Press, 1991.

Wicker, Elmus. Banking Panics of the Gilded Age. Cambridge: Cambridge University Press, 2000. 
